OPEN ACCESS

Edited by:

Sachin Kumar,

Sardar Swaran Singh National Institute of Renewable Energy, India

Reviewed by:

Mohanakrishna Gunda,

Qatar University, Qatar

Ao Xia,

Chongqing University, China

*Correspondence: Jeyakumar Rajesh Banu rajeshces@gmail.com

Specialty section: This article was submitted to

Bioenergy and Biofuels,

a section of the journal

Frontiers in Energy Research

Received: 25 May 2019

Accepted: 24 July 2019

Published: 21 August 2019

Citation:

Kumar D, Eswari AP, Park J-H, Adishkumar S and Banu JR (2019)

Biohydrogen Generation From Macroalgal Biomass, Chaetomorpha antennina Through Surfactant Aided

Microwave Disintegration.

Front. Energy Res. 7:78.

doi: 10.3389/fenrg.2019.00078

\section{Biohydrogen Generation From Macroalgal Biomass, Chaetomorpha antennina Through Surfactant Aided Microwave Disintegration}

\author{
Dinesh Kumar ${ }^{1}$, Arumugapal Parvathy Eswari ${ }^{1}$, Jeong-Hoon Park ${ }^{2,3}$, \\ Somanathan Adishkumar ${ }^{1}$ and Jeyakumar Rajesh Banu ${ }^{1 *}$ \\ ${ }^{1}$ Department of Civil Engineering, Anna University Regional Campus, Tirunelveli, India, ${ }^{2}$ Department of Civil and \\ Environmental Engineering, Northwestern University, Evanston, IL, United States, ${ }^{3}$ School of Civil, Environmental and \\ Architectural Engineering, Korea University, Seoul, South Korea
}

This present work intends to improve on the possibility of enhancing solubilization and biohydrogen $\left(\mathrm{H}_{2}\right)$ production from Chaetomorpha antennina (marine macroalgae) through surfactants (ammonium dodecyl sulfate-ADS) aided with microwave disintegration pretreatment (SMD). Microwave disintegration (MD) was implemented by varying power intensity from 10 to $70 \%$ for the time period of 0 to $30 \mathrm{~min}$. In microwave disintegration (MD), maximum soluble organic release of 1,260 mg/L and solubilization of $14.6 \%$ were achieved within $15 \mathrm{~min}$. Through surfactants, soluble organic release improves up to $1,490 \mathrm{mg} / \mathrm{L}$ at the optimum MD power condition of $40 \%$. High solubilization of $17.3 \%$ was achieved at dosage of $0.0035 \mathrm{~g} / \mathrm{g}$ TS. Higher $\mathrm{H}_{2}$ generation of $74.5 \mathrm{ml} / \mathrm{g}$ COD was obtained in the SMD method. SMD pretreatment therefore reduces pretreatment time and increases the organic release compared to MD.

Keywords: Chaetomorpha antennina, microwave, solubilization, ammonium dodecyl sulfate, biohydrogen, specific energy

\section{INTRODUCTION}

Decreasing oil wealth, fuel demand and environmental effects stimulate the exploration of efficient and clean energy. Clean and renewable energy are alternatives that can cut carbon dioxide emissions, cultivate independent energy sources, and shape a nation's economy. Renewable energy production has been initiated in various forms such as wind farms, solar fields, and biomass, although biofuel production is the most capable alternative energy source. Biofuels have been developed as an alternative energy source to conventional fossil fuels in transportation (Sudhakar and Premalatha, 2012). Biohydrogen has numerous ecological benefits such as efficient waste management (Rai and Singh, 2016). Biohydrogen production using biological methods is a manifold metabolic process facilitated through microorganisms; effective $\mathrm{H}_{2}$ generation and steady system performance is necessary to make this method accessible. The use of various substrates impact hydrogen production due to the structure of the biomass which needs optimum disintegration to enhance hydrogen production (Wang and Yin, 2018). Various biomasses such as waste activated sludge (Banu et al., 2018a), rice straw (Kannah et al., 2019), and macro algae (Kumar et al., 2018), have been used to produce biohydrogen. Macro algae 
is an effective bio-feedstock used for renewable fuel production and has attracted increased attention in recent years (Pjohn and Anisha, 2011). Indeed, intact macro algal cell walls result in slow autolysis and extend the fermentative $\mathrm{H}_{2}$ production process (Liu and Wang, 2014). To quicken the solubilization of macro-algal biomass, it is essential to disintegrate the biomass with optimal pretreatment methods. Pretreatment methods such as biological, thermal, mechanical and chemical, could abolish cell walls and enhance the hydrogen production. Algal cell walls disintegrate with pretreatment resulting in release of inner components such as proteins, carbohydrates etc. Researchers have studied numerous pretreatments to disintegrate the algal biomass, such as biological (Yahmed et al., 2017), chemical (Park et al., 2011), mechanical (Montingelli et al., 2016), thermal (González-Fernández et al., 2013), and combinations of the above mentioned pretreatments. $\mathrm{H}_{2}$ generation from macro algae has numerous advantages such as cultivation ease, rapid growth, high $\mathrm{CO}_{2}$ capture, long with having rich protein and carbohydrate content.

Microwave irradiation is an efficient treatment used to disintegrate the biomass. Yeneneh (2014) stated the advantages of microwave pretreatment such as quick heating, both thermal and athermal effects, heat penetration effects, use of less space, and non-contact heating. Compared to conventional heating, microwave heating is rapid and more effective (Yoo et al., 2014), however, it requires more energy which makes this treatment unattractive. Nevertheless, this could be fixed by combining microwave heating with other pretreatments such as a chemical pretreatment, to enhance treatment efficiency (Eswari et al., 2017). Anaerobic digestion (AD) is limited by an inadequate hydrolysis of extra polymeric substances or biopolymer compounds such as proteins and carbohydrates and a limited algal biomass, causing poor volatile fatty acid production. Researchers have studied surfactant aided pretreatment as an alternate approach to the AD process (Kavitha et al., 2016; Tamilarasan et al., 2017; Kumar et al., 2018). Carvalho et al. (2004) states that bacteria utilize surfactants as a carbon source. Surfactants might help in releasing confined enzymes which present on the surface of cells or in the cell. Thus, a soluble organic release may improve the hydrolysis rate. Furthermore, surfactants may act as an enzyme modulator, increasing enzyme activity at a low dosage. A high dosage may have a dissimilar effect.

In this study, ammonium dodecyl sulfate (ADS), is a surfactant used in microwave heating to enhance the pretreatment and improve the hydrogen production. Surfactants lower the surface tension and accumulate the biomass during pretreatment. The surfactant used in this study was in liquid form, and might dissolve in water during pretreatment thus it is not recycled in this process. It disrupts the hydrogen bonding in water and can be easily hydrolyzed by microbes. Additionally, a low concentration of the surfactant is used, so it cannot affect $\mathrm{H}_{2}$ microbes. Efficient biohydrogen production from a marine algal biomass, through combined microwave heating with a surfactant at optimum conditions, with minimum energy spent was carried out in this study. Graphical abstract of this study is shown as Figure S1 of Supplementary Information. The main intent of this study is to (1) assess the microwave disintegration effectiveness, (2) to investigate the surfactants effect of microwave on algae disintegration (3) to investigate the energy spent during the pretreatment and its effect (4) to assess the impact of combined treatment in biohydrogen production.

\section{EXPERIMENT PROCEDURES}

\section{Algae Sampling}

Chaetomorpha antennina, the marine macroalgae used in this experiment, was collected from the southern shoreline of Tirunelveli, Tamilnadu, India. The collected algal samples were cleaned by removing sand and other undesirable particles, using water. The algal samples were then dried out in shady conditions for between 48 to $72 \mathrm{~h}$. Table 1 shows the characteristics of the macroalgae sample.

\section{Microwave Disintegration (MD)}

Microwave disintegration was carried out in this study using a commercial microwave oven (IFB, model-30SC2) with an output power of $900 \mathrm{~W}$. Poly(tetrafluoroethylene) (PTFE) vessel was used to carry the experiment to the microwave oven. Using a PTFE cover, water loss was reduced during the MD process. Ten grams of macroalgae inserted in the PTFE vessel with $500 \mathrm{ml}$ of water. The experiment was done with the power conditions varying from between 0.09 to $0.63 \mathrm{~kW}$ (i.e., 10 to $70 \%$ power intensity). Using a thermometer, the temperature conditions were observed, varying from $10^{\circ} \mathrm{C}$ to $120^{\circ} \mathrm{C}$ during the $\mathrm{MD}$ process. Further analysis of the organic release was done by collecting the treated samples at interval times varying from 10 to $30 \mathrm{~min}$.

\section{Surfactant Aided Microwave Disintegration (SMD)}

The surfactant aided microwave disintegration (SMD) process was performed in $10 \mathrm{~g}$ of macroalgae with $500 \mathrm{ml}$ water using varying surfactant dosages of 0.0005 to $0.005 \mathrm{~g} / \mathrm{g}$ TS. Ammonium dodecyl sulfate, an anionic surfactant (30\% wt.) was used in this process. The experiment was carried out in a microwave power condition of $0.36 \mathrm{~kW}$ which was considered the optimum condition achieved for the MD process. Due to contrasting effects at a high dosage of the surfactant, in this experiment a very low dosage was used to improve solubilization. Samples were collected at regular time intervals and analyzed.

TABLE 1 | Macroalgal biomass characteristics.

\begin{tabular}{llc}
\hline S. No. & Parameters & Composition in \% (dry weight) \\
\hline 1 & Protein & 48.5 \\
2 & Carbohydrate & 24 \\
3 & Lipids & 2 \\
4 & Carbon & 29.2 \\
5 & Nitrogen & 4 \\
6 & Cellulose & 5.2
\end{tabular}




\section{Specific Energy (SE) Measurement}

In $\mathrm{MD}$, the energy used for the process was measured as specific energy. Specific energy is considered to evaluate the probability of solubilization. The following equation defines the specific energy calculation:

$$
\mathrm{SE}=\left(\mathrm{Pi}^{*} \mathrm{~T} d\right) /\left(\mathrm{Vd}^{*} \mathrm{Si}\right)
$$

where

SE- Specific energy (kJ/kg TS),

$\mathrm{P} i$, Microwave power intensity $(\mathrm{kW})$,

$\mathrm{T} d$, Disintegration time (sec),

$\mathrm{V} d$, Volume of sample used for disintegration (L), and

$\mathrm{Si}$, Total solids initially used $(\mathrm{kg})$.

\section{Fermentation Test}

The effect on hydrolysis and acidification of surfactant aided microwave pretreatment can be evaluated using a fermentation test. This was done using the control samples (untreated samples), MD and SMD. This fermentation test was carried out in serum bottles for $72 \mathrm{~h}$ with a sample and slurry taken at a ratio of 9:1. $50 \mathrm{~mm}$ of 2-bromo ethane sulphonic acid (BESA) was added to each bottle to inhibit the growth of methanogenic bacteria and to selectively enhance the hydrogen producing bacteria (Mohanakrishna et al., 2010). Nitrogen gas was introduced into all the sample bottles to eradicate $\mathrm{O}_{2}$. The bottles were then tightly sealed using stoppers and placed in a shaker with 150 $\mathrm{rpm}$ at $35^{\circ} \mathrm{C}$.

\section{Biohydrogen Production Assay (BHP)}

A biohydrogen production assay (BHP) was done for the control, MD and SMD samples in a mesophilic environment, to evaluate the $\mathrm{H}_{2}$ generation. BHP assays were carried out in $300 \mathrm{ml}$ reactors (serum bottles) of which $150 \mathrm{ml}$ was used as the working volume. The experiments were conducted in triplicate. The macroalgae treated sample, inoculum and nutrients were filled as 70,25 , and $5 \%$ in each reactor bottle in fermentation conditions (Kumar et al., 2019). The digested sludge was collected from an anaerobic digester in a wastewater treatment plant and was used as inoculum in this experiment. Since the inoculum consists of mixed consortia, it was heated at $100^{\circ} \mathrm{C}$ for $30 \mathrm{~min}$ to eliminate the methanogenic microbes and to enable the enhancement of spore forming acidogenic hydrogen producing microbes (Mohan et al., 2007).

To maintain $\mathrm{AD}$ condition, $\mathrm{N}_{2}$ gas was purged in the remaining space in the bottle for $10 \mathrm{~min}$, which eradicated the presence of $\mathrm{O}_{2}$ in the bottles. The bottles were then compactly enfolded with rubber stoppers. Finally, the bottles were kept in a shaker, incubated at $37^{\circ} \mathrm{C}$ at $130 \mathrm{rpm}$. Through this displacement method, the total biogas generated can be identified in each sample bottle using a needle which is injected into the stopper. A gas chromatograph with a thermal conductivity detector and a stainless column packed with Porapak Q $(3.25 \mathrm{~mm}$ in diameter, $2 \mathrm{~cm}$ length with $80 / 100$ mesh) was used to calculate the hydrogen production. The experiments were done in triplicate. To estimate the cumulative $\mathrm{H}_{2}$ yield, the modified Gompertz equation was used,

$$
\mathrm{C}_{\mathrm{H}}=\mathrm{H}_{\mathrm{p}}^{*} \exp \left[-\exp \left(-\mathrm{p}\left(\mathrm{H}_{\mathrm{i}}-\mathrm{H}_{1}\right)\right]\right.
$$

where $\mathrm{C}_{H}$ is the cumulative $\mathrm{H}_{2}$ produced $(\mathrm{ml}), \mathrm{H}_{\mathrm{p}}$ is the $\mathrm{H}_{2}$ generation ( $\mathrm{ml} \mathrm{H}_{2} / \mathrm{g} \mathrm{COD}$ ), $p$ is the maximum $\mathrm{H}_{2}$ generation rate $\left(\mathrm{ml} \mathrm{H} \mathrm{H}_{2} / \mathrm{g} \mathrm{COD} \mathrm{d}\right), \mathrm{H}_{\mathrm{i}}$ is the initial day and $\mathrm{H}_{1}$ is the lag phase (days).

\section{Energy Analysis}

An energy analysis is an important parameter required to implement the process on a large scale. In this study, energy analysis was evaluated using the energy used to treat $1 \mathrm{~kg}$ of the algal biomass sample and the energy gained as $\mathrm{H}_{2}$ gas. The energy spent for the disintegration was considered as input energy and is shown in equation (3).

$$
\mathrm{Ei}=\mathrm{P}^{*} \mathrm{~T}^{*} \mathrm{~V}^{*} \mathrm{~S}
$$

Where,

Ei, Input energy (kWh),

$\mathrm{P}$, Power utilized for the process $(\mathrm{kW} / \mathrm{kg})$

$\mathrm{T}$, Time used for disintegration (hours)

$\mathrm{V}$, Reactor volume $\left(\mathrm{m}^{3}\right)$

$\mathrm{S}$, Substrate $\left(\mathrm{kg} / \mathrm{m}^{3}\right)$

The energy gained as hydrogen from the pretreated sample as the output energy was achieved using Equation (4), considering the organic loading, hydrogen yield gained and reactor volume.

$$
\text { Eo }=B^{*} L^{*} H^{*} V^{*} F
$$

Where,

Eo, Output energy (kWh)

$\mathrm{B}$, Biodegradability of algal biomass (gCOD/gCOD)

$\mathrm{L}, \mathrm{COD}$ load $\left(\mathrm{gCOD} / \mathrm{m}^{3}\right)$

$\mathrm{H}$, Hydrogen yield $\left(\mathrm{m}^{3} / \mathrm{gCOD}\right)$

$\mathrm{V}$, Reactor volume $\left(\mathrm{m}^{3}\right)$

F, Biohydrogen conversion factor $\left(1 \mathrm{~m}^{3}\right.$ is equal to $\left.3.5 \mathrm{kWh}\right)$

(Zittel et al., 1996)

Net energy is the difference between the energy gained and energy spent and was calculated using equation (5).

$$
\mathrm{E} n=\mathrm{E} o-\mathrm{E} i
$$

Where,

En, Net energy (kWh)

Eo, Output energy (kWh)

Ei, Input energy (kWh)

Energy gain and loss were identified through positive and negative net energy which was obtained in the MD and SMD process. The output energy generated should at least be more than the input energy. The energy ratio can be expressed as,

$$
\mathrm{E} r=\mathrm{E} o / E i
$$


Where,

$\mathrm{E} r$, Energy ratio

Eo, Output energy (kWh)

Ei, Input energy (kWh).

\section{Analytical Methods}

Standards methods (APHA, 2005) were used to determine TCOD, SCOD, and volatile fatty acids (VFA). Carbohydrates and proteins were determined using the anthrone method (Trevelyan et al., 1952) and Lowry's method (Lowry et al., 1951), respectively.

\section{RESULTS AND DISCUSSIONS}

\section{Impact of MD in Soluble Organic Release}

Microwave irradiation works on two main principles: thermal and athermal (non-thermal) effects. The thermal effect generates heat due to the absorption of microwave energy in the aqueous phase or by organic matters that are marked by either constant or induced polarization (Yu et al., 2010). This effect increases the temperature and pressure, consequently helping to weaken the cell walls, thus aiding in hydrolysis. Further, Banik et al. (2003) stated that athermal effects might also lead to biomass pre-treatment. Athermal effects occur due to the microwave force dipoles that support the oscillating electric field, which results in the distraction of $\mathrm{H}_{2}$ bonds. This rift in $\mathrm{H}_{2}$ bonds could result in the devastation of cell walls as well as disintegration, thereby enhancing hydrolysis (Kumar et al., 2019). Other effects such as dielectric effects, magnetic field coupling, and electroporation are responsible for degrading the biomass through microwave. Chaetomorpha sp. was pretreated in a microwave of between 0.09 to $0.63 \mathrm{~kW}$ (power intensity: $10-70 \%$ ) at 0 to $45 \mathrm{~min}$.
The consequences of microwave disintegration on the soluble organic release in various powers at different times is shown in Figure 1. In microwave irradiation, the power intensity of the microwave is an important parameter of the soluble organic release (Kavitha et al., 2018). At the $15 \mathrm{~min}$ time period, the release may become significant. A minor soluble organic release of 700 to $910 \mathrm{mg} / \mathrm{L}$ occurred at a power intensity of 0.09 to $0.27 \mathrm{~kW}$. This inconsequential release occurs due to low power usage which induces algal biomass breakdown. There may be an impulsive rise of soluble organic release at $0.36 \mathrm{~kW}$. Heat rapidly breaches the algae and then breaks down and releases the soluble organics into the aqueous phase. Furthermore, the soluble organic release in the MD process can be separated into two stages: a quick release stage and a slow release stage. In MD, a quick increase of organic release was identified at $15 \mathrm{~min}$. It happens because algal cells break due to the thermal and athermal effects. These effects are worth noting as the organics then break down biomolecules such as carbohydrates and proteins that are released into the aqueous medium enhancing the solubilization rate. Additionally, soluble organic increments occur at 0.45 to $0.63 \mathrm{~kW}$ but insignificant release occurs when consuming energy. It is therefore worth noting that the soluble organic release of $1,260 \mathrm{mg} / \mathrm{L}$ occurs at $0.36 \mathrm{~kW}$ at $15 \mathrm{~min}$. Based on the results, it was concluded that at $15 \mathrm{~min}$ at $0.36 \mathrm{~kW}$ was optimal power required for the $\mathrm{MD}$ treatment process.

\section{Influence of Surfactants on Biopolymer Release and Solubilization}

In surfactant aided microwave disintegration (SMD), algal sample was disintegrated by varying dosages of ADS from

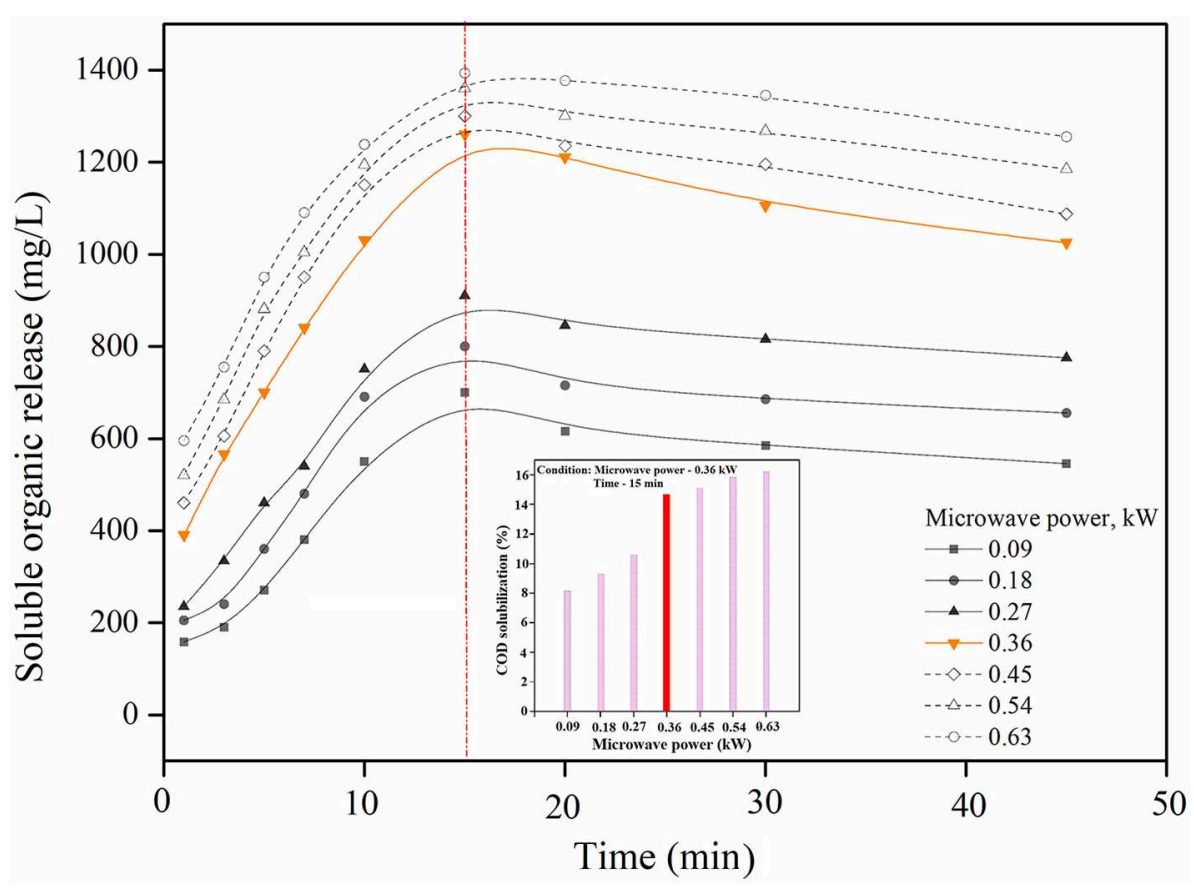

FIGURE 1 | Impact of microwave disintegration on soluble organic release. 
0.0005 to $0.005 \mathrm{~g} / \mathrm{g}$ TS at optimum microwave disintegration conditions of $0.36 \mathrm{~kW}$ at $15 \mathrm{~min}$. Surfactant aided microwave could effectively improve the solubilization of algal biomass in comparison to microwave disintegration. During disintegration, the organics released cause aggregation in the soluble phase and reduces the effectiveness of the treatment. By adding surfactants, a layer formed near the fragmented algae sample thus lowering the surface and avoiding cluster formation. Mohanty and Mukherji (2012) stated that surfactants can also increases the permeability of the cell wall and would then be adsorbed on the membrane, releasing inner components in the biomass by persuading the cell cleavage. The addition of surfactants therefore effectively improve the treatment process (Dhand et al., 2015). Improving solubilization through a more organic release and
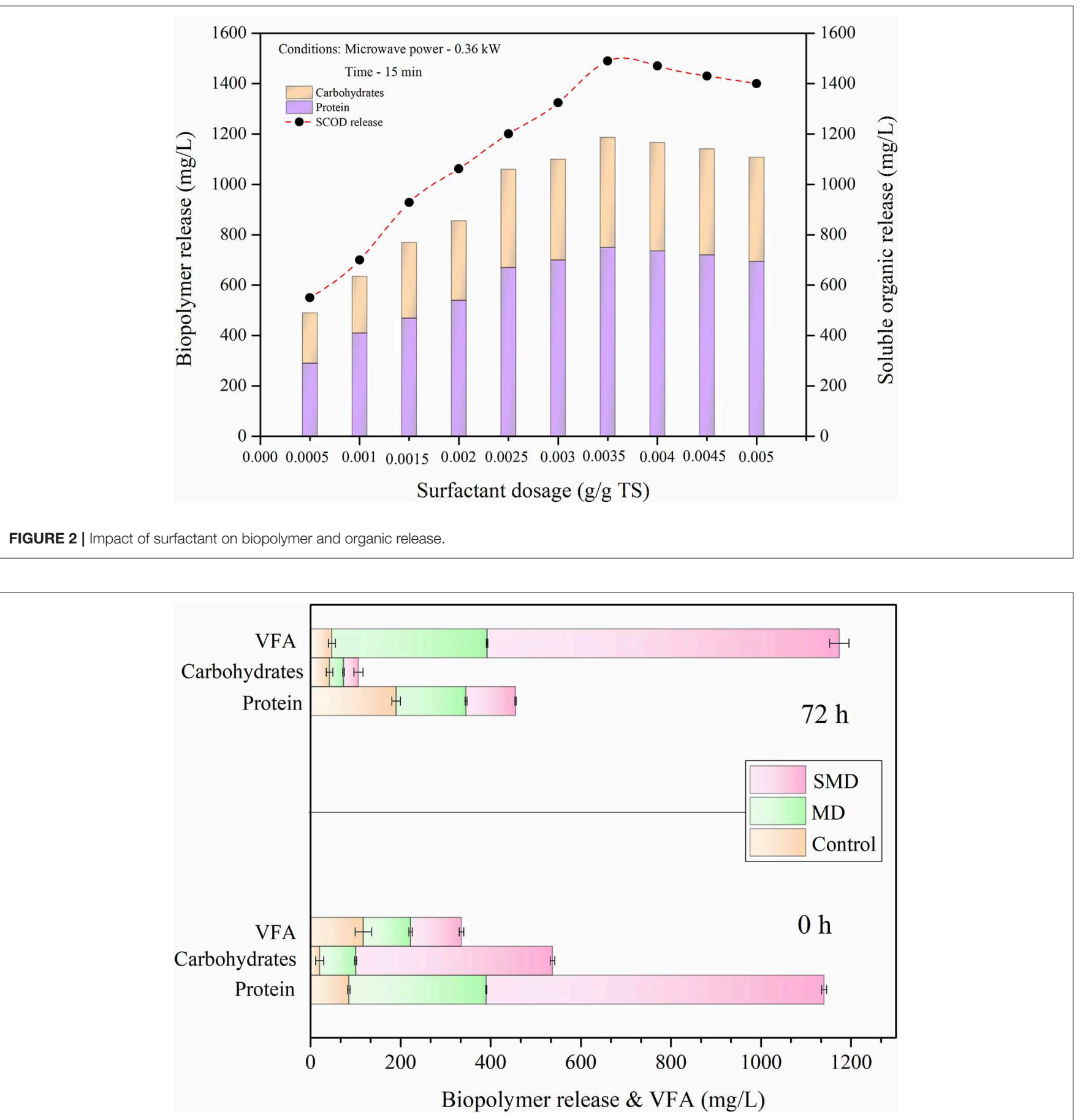

FIGURE 3 | Impact of MD and SMD on anaerobic fermentation. 


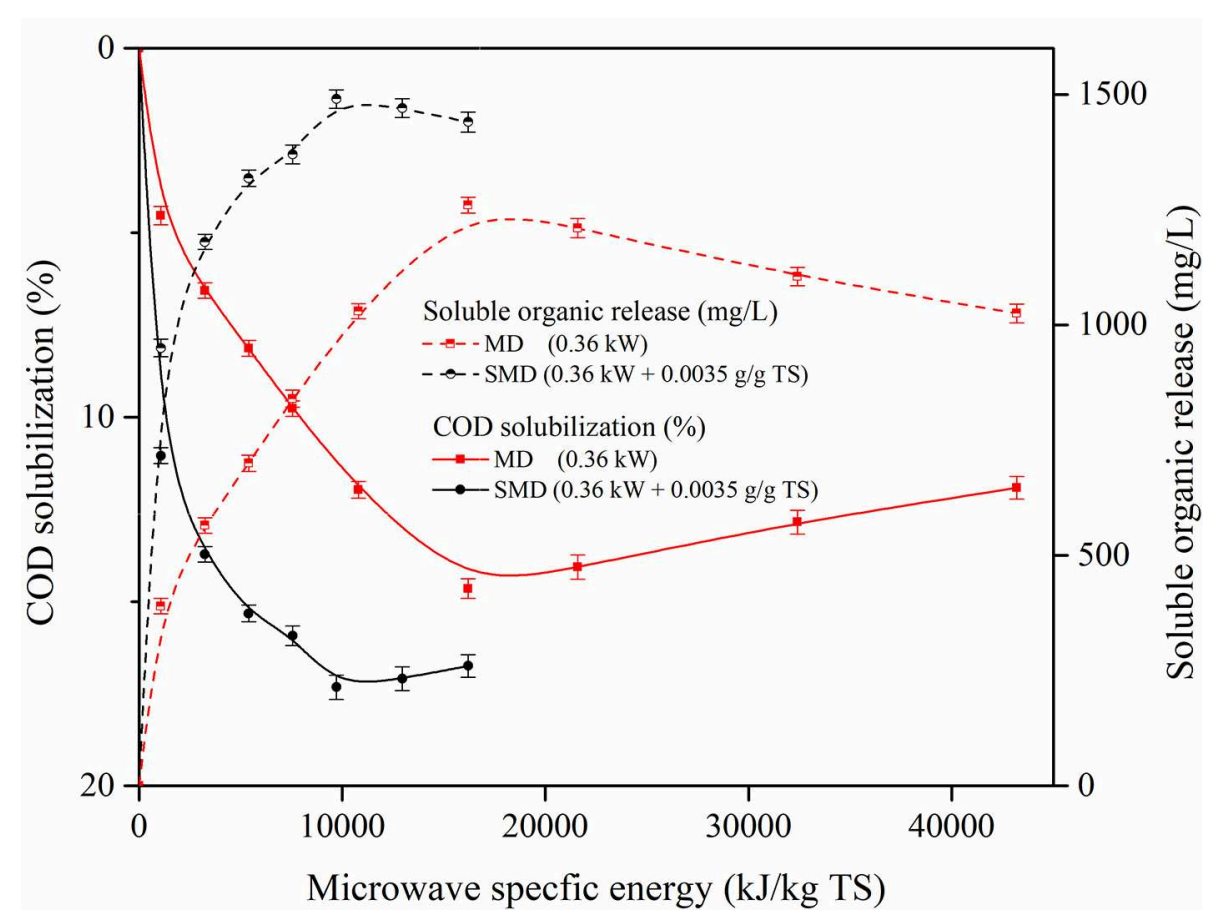

FIGURE 4 | Impact of specific energy on solubilization and organic release in MD and SMD.

TABLE 2 | Kinetic data relevant to soluble organic release enhanced by microwave irradiation pre-treatment at different temperatures.

\begin{tabular}{|c|c|c|c|c|c|c|}
\hline Treatment & $\begin{array}{l}\text { Specific energy } \\
\text { (kJ/kgTS) }\end{array}$ & Temp $^{\circ} \mathrm{C}$ & Dynamic equation & $\begin{array}{l}\text { Rate constant } \\
\qquad\left(\mathrm{h}^{-1}\right)\end{array}$ & Coefficient- $R^{2}$ & $\begin{array}{c}\text { Activation } \\
\text { energy } \\
\text { (kJ/mol) }\end{array}$ \\
\hline \multirow{4}{*}{$\begin{array}{l}\text { Surfactant aided } \\
\text { microwave } \\
\text { disintegration (SMD) }\end{array}$} & 5,400 & 52 & $Y=-20.20 x-132.9$ & 20.20 & 0.931 & \\
\hline & 7,560 & 67 & $Y=-20.80 x-138.3$ & 20.80 & 0.890 & \\
\hline & 9,720 & 76 & $Y=-22.69 x-152.8$ & 22.69 & 0.904 & \\
\hline & 16,200 & 92 & $Y=20.63 x-137.4$ & 20.63 & 0.909 & \\
\hline \multirow{3}{*}{$\begin{array}{l}\text { Microwave } \\
\text { disintegration (MD) }\end{array}$} & 5,400 & 46 & $Y=-17.42 x-93.44$ & 17.42 & 0.450 & 0.415 \\
\hline & 7,560 & 57 & $Y=-19.53 x-110.3$ & 19.53 & 0.402 & \\
\hline & 10,800 & 71 & $Y=-24.42 x-145.4$ & 24.42 & 0.506 & \\
\hline \multirow{6}{*}{$\begin{array}{l}\text { Conventional } \\
\text { treatment }(\mathrm{CT})\end{array}$} & 45,000 & 46 & $Y=-26.15 x-143.8$ & 26.15 & 0.202 & 0.723 \\
\hline & 58,500 & 57 & $Y=-28.35 x-196.3$ & 28.35 & 0.39 & \\
\hline & 121,500 & 71 & $Y=-31.15 x-262.5$ & 31.15 & 0.41 & \\
\hline & 135,000 & 84 & $Y=-36.25 x-292.3$ & 36.25 & 0.35 & \\
\hline & 157,500 & 91 & $Y=-35.25 x-285.3$ & 35.25 & 0.51 & \\
\hline & 180,000 & 93 & $Y=-40.28 x-305.6$ & 40.28 & 0.49 & \\
\hline
\end{tabular}


at minimum energy consumption and time, are the probable benefits that could be attained when surfactants are introduced in microwave disintegration (Banu et al., 2018b). In this experiment, ADS, an anionic surfactant was used that improves combining activity and is capable of lowering surface tensions. Figure 2 displays the impact of surfactants in the soluble organic release. Soluble organic release starts slightly increasing by between 550 to $1,490 \mathrm{mg} / \mathrm{L}$ by adding a dosage of between 0.0005 to $0.0035 \mathrm{~g} / \mathrm{g}$ TS. This soluble organic release increment could be due to the effectiveness of surfactant dosage in microwave which prompts disintegration and prevents biomass aggregation. Beyond the $0.0035 \mathrm{~g} / \mathrm{g}$ TS dosage, a minor decrement found might be found. This is due to the evaporation loss which occurs in microwave irradiation. The soluble organic release of between 1,470 to $1,400 \mathrm{mg} / \mathrm{L}$ was achieved in a dosage of between 0.004 to $0.005 \mathrm{~g} / \mathrm{g} \mathrm{TS}$, respectively. Therefore, at a $0.0035 \mathrm{~g} / \mathrm{g}$ TS surfactant dosage the organic release increases up to 2.7 times $(1,490 \mathrm{mg} / \mathrm{L})$ than at the initial surfactant dosage of 0.0005 $\mathrm{g} / \mathrm{g}$ TS $(550 \mathrm{mg} / \mathrm{L})$. This increase occurs due to lowering of surface tensions by surfactants which prevents the aggregation of released organic matter and promotes organic release into the

TABLE 4 | Kinetics parameters for biohydrogen production in treated samples.

\begin{tabular}{llcccc}
\hline S. No. & Samples & $\begin{array}{c}\mathbf{a} \\
\mathbf{m L ~} \mathbf{~}_{\mathbf{2}} \mathbf{g} \text { COD }\end{array}$ & $\begin{array}{c}\mathbf{K} \\
\text { (mL/g COD d) }\end{array}$ & $\begin{array}{c}\mathbf{H}_{\mathbf{l}} \\
\text { (days) }\end{array}$ & $\boldsymbol{R}^{\mathbf{2}}$ \\
\hline 1 & SMD & 74.5 & 0.3049 & 3.01 & 0.9822 \\
2 & MD & 63 & 0.3010 & 4.6 & 0.9823 \\
3 & Control & 19 & 0.3191 & 5.5 & 0.9750
\end{tabular}

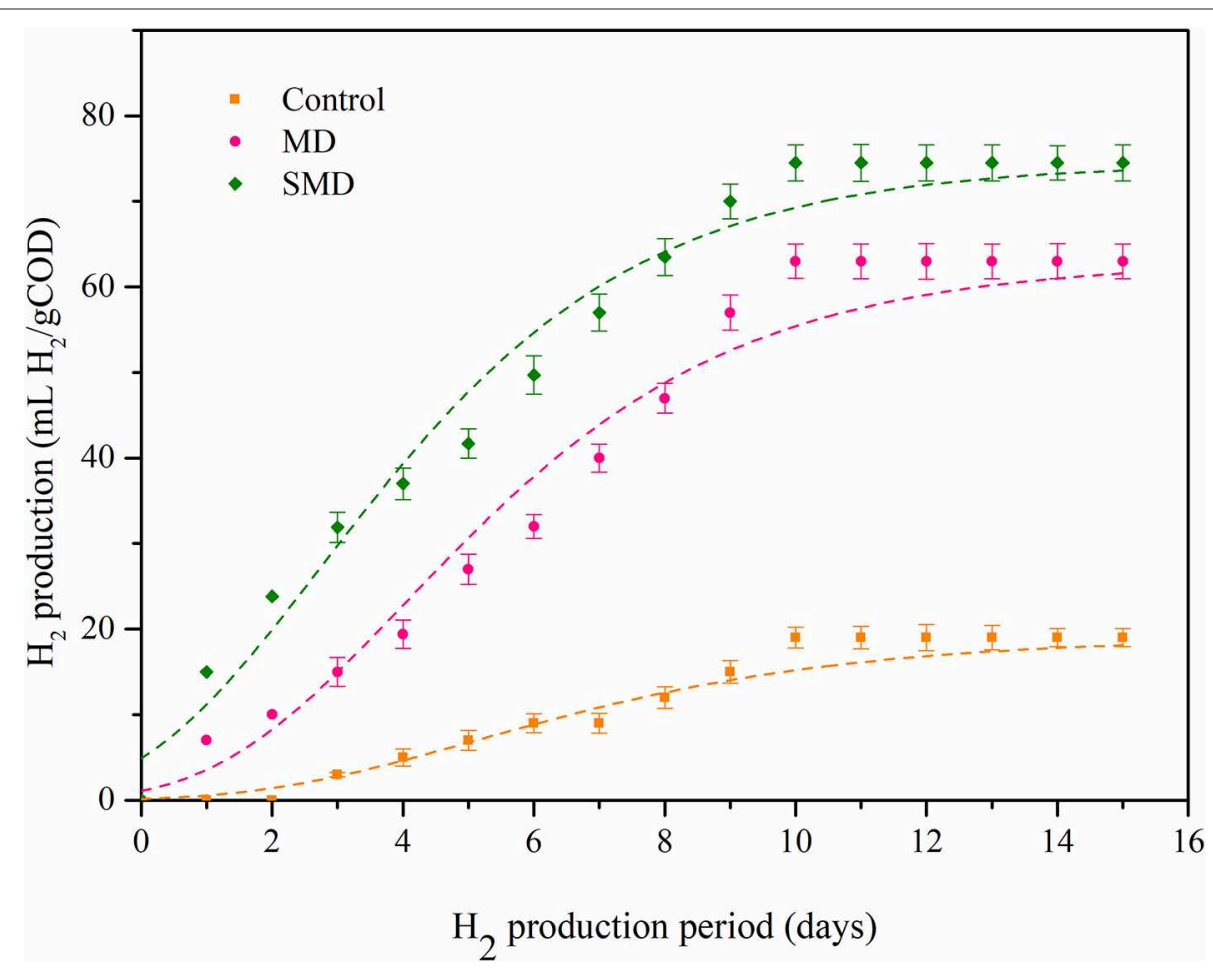

FIGURE 5 | Cumulative biohydrogen production in all the samples.

TABLE 3 | Biohydrogen production using different algae samples.

\begin{tabular}{|c|c|c|c|c|}
\hline Sample & Pretreatment methods & Pretreatment condition & Hydrogen Production & Reference \\
\hline Laminaria japonica & Ultrasonic & Frequency-20 kHz & $23.56 \mathrm{~mL} \mathrm{H}_{2} / \mathrm{g}$ substrate & Liu and Wang, 2014 \\
\hline Laminaria digitata & Thermal + Acidic & $\begin{array}{l}\text { Dilute } \mathrm{H}_{2} \mathrm{SO}_{4}-2.5 \% \\
\text { Temperature- } 135^{\circ} \mathrm{C} \\
\text { Time- } 15 \mathrm{~min}\end{array}$ & $85.0 \mathrm{~mL} / \mathrm{g}$ VS & Xia et al., 2016 \\
\hline Ulva reticulata & Disperser + Surfactant & $\begin{array}{l}\text { Disperser rpm-10000 } \\
\text { Surfactant dosage-21.6 mg/L }\end{array}$ & $63 \mathrm{~mL} \mathrm{H}_{2} / \mathrm{g} \mathrm{COD}$ & Kumar et al., 2018 \\
\hline Sea eelgrass & Disperser + surfactant & $\begin{array}{l}\text { Disperser rpm-10,000 } \\
\text { Surfactant dosage-0.005 g/g TS }\end{array}$ & $23.2 \mathrm{~mL} \mathrm{H} / \mathrm{g} \mathrm{VS}$ & Banu et al., 2019 \\
\hline Chaetomorpha antennina & Microwave + surfactant & $\begin{array}{l}\text { Power-0.36 kW } \\
\text { Surfactant dosage-0.0035 g/g TS }\end{array}$ & $74.5 \mathrm{~mL} \mathrm{H} / \mathrm{g} \mathrm{COD}$ & This study \\
\hline
\end{tabular}


medium. Release of biomolecules (proteins and carbohydrates) were $490 \mathrm{mg} / \mathrm{L}$ at $0.0005 \mathrm{~g} / \mathrm{g}$ TS. Biomolecule release was then increased to $1,187 \mathrm{mg} / \mathrm{L}$ at a surfactant dosage of $0.0035 \mathrm{~g} / \mathrm{g}$ TS. Increasing energy and prolonging time might cause a loss in organics instead of solubilization. In this study, the SMD process considerably increased the solubilization by up to $17.3 \%$. Thus, SMD might reduce the energy spent in pretreatment and improve the economic viability.

\section{Impact of SMD on VFA Production}

VFA production of the control, MD and SMD of macro algae was evaluated and is displayed in Figure 3. Complex biopolymer structures such as proteins and carbohydrates that are present in algal biomass where converted into peptides, amino acids, and sugars. These simple structures were later converted into VFA in the acidogenesis process which followed (Sambusiti et al., 2015). Due to thermal effects, biomass disintegrates and releases some organic matter. Surfactants are able to change surface tension improving the solubilization because of its characteristic high surface activity. Therefore, biopolymer substances (proteins and carbohydrates) might be released from samples into the aqueous phase. Bhuyan (2010) stated that surfactants may be helpful in the utilization of proteins and carbohydrates. Microbes can utilize released biopolymers to produce VFA and hydrogen effectively.

Protein and carbohydrate concentrations in MD and SMD samples were 305 and $750 \mathrm{mg} / \mathrm{L}$ respectively at $0 \mathrm{~h}$ and decreased to 95 and $110 \mathrm{mg} / \mathrm{L}$ at $72 \mathrm{~h}$. Similar to proteins, the carbohydrate concentration of $\mathrm{MD}$ and $\mathrm{SMD}$ reduced from 80 and $437 \mathrm{mg} / \mathrm{L}$ (at $0 \mathrm{~h}$ ) to 40 and $33 \mathrm{mg} / \mathrm{L}$ (at $72 \mathrm{~h}$ ) during fermentation. This happens because the substrate is efficiently consumed by microbes (Tamilarasan et al., 2017). The concentration of carbohydrates and proteins in the MD and SMD process decreased and converted into VFA and $\mathrm{H}_{2}$. Moreover, amylolytic and cellulolytic microbes present in the inoculum rapidly utilized the sugar compounds into VFA (Banu et al., 2019). In MD and SMD, the sugar utilization rate was 21 and $86 \%$, respectively. Due to the effect of SMD, it was observed that protein and carbohydrate reduction and sugar utilization were higher. $\mathrm{pH}$ was 6.8 at initial fermentation stage, while at the final stage after VFA production, the $\mathrm{pH}$ was 5.5. In fermentation, higher VFA accumulation leads to biohydrogen production (Xia et al., 2015). Moreover, pH 5.5 is an effective condition for hydrogen production. High VFA accumulation was observed in SMD of $770 \mathrm{mg} / \mathrm{L}$ compared with $\mathrm{MD}$ and the control (Yang and Wang, 2018). Fermentative microbes utilize the disintegrated samples which is the reason behind the generation of more VFA after $72 \mathrm{~h}$. It was thus observed

TABLE 5 | Comparison of energy analysis between MD and SMD process.

\begin{tabular}{lccccc}
\hline S. No. Samples & $\begin{array}{c}\text { Input energy } \\
\text { (kWh/kg algal } \\
\text { biomass) }\end{array}$ & $\begin{array}{c}\text { Output energy } \\
\text { (kWh/kg algal } \\
\text { biomass) }\end{array}$ & $\begin{array}{c}\text { Net energy } \\
\text { (kWh/kg algal } \\
\text { biomass) }\end{array}$ & $\begin{array}{c}\text { Energy } \\
\text { ratio }\end{array}$ \\
\hline 1 & MD & 0.09 & 0.0126 & -0.0762 & 0.14 \\
2 & SMD & 0.054 & 0.0193 & -0.0347 & 0.357
\end{tabular}

that the SMD process enhances the fermentation process, producing more hydrogen.

\section{Effect of Specific Energy (SE) on Solubilization in MD and SMD}

$\mathrm{SE}$ is an important aspect that determines cost-effective possibilities and the energy expended in microwave pretreatment. Microwave irradiation disintegrates the algal cell wall and improves solubilization through thermal and athermal effects, however, microwave pretreatment may require more energy and thus increases the cost of pretreatment. It shows that microwave alone is not cost effective and requires more energy. Through combined treatments, organic release can be enhanced while energy consumption and pretreatment time are reduced leading to an economical advantage. Figure 4 illustrates the impact of SE on soluble organic release in $\mathrm{MD}$ and SMD pretreatment. The rapid soluble organic release in 0 to $10,200 \mathrm{~kJ} / \mathrm{kg}$ TS is noted in Figure 4. Because of disintegration, the organic matter in the biomass released at the soluble phase could be the reason for this rapid increment. During this phase, $1,260 \mathrm{mg} / \mathrm{L}$ and $14.6 \%$ of soluble organic release and solubilization, respectively, was found at SE of $16,200 \mathrm{~kJ} / \mathrm{kg}$ TS. Furthermore, a decrease in organic release might be observed as $1,210 \mathrm{mg} / \mathrm{L}$ in $21,600 \mathrm{~kJ} / \mathrm{kg}$ TS. There might be a slow degradation that continues from 21,600 to $43,200 \mathrm{~kJ} / \mathrm{kg}$ TS. Similar tendencies might possibly follow in SMD and it was a soluble organic release of $1,490 \mathrm{mg} / \mathrm{L}$ in $9,720 \mathrm{~kJ} / \mathrm{kg}$ TS at 9 min was observed, which is higher than MD. When power increases, the pretreatment temperature also increases which might cause evaporation loss. Because of evaporation loss, the organic matter released in the soluble phase could decrease in higher SE (Ebenezer et al., 2015). So, beyond 9,720 kJ/kg TS, there might be a decrement in soluble organic release and solubilization. Thus, it can be concluded that the SMD process in the algae sample could improve $\mathrm{H}_{2}$ generation with less energy consumption than MD.

\section{Thermodynamic Calculation for MD and SMD}

High energy and more time is required for microwave disintegration, while in SMD effective solubilization was achieved in little time with less energy consumption. Therefore, SMD is more operative than MD. For a thermodynamic analysis of MD and SMD, soluble organic release was considered. Microwave power varying from 0.09 to $0.63 \mathrm{~kW}$ was considered for the study with temperatures of between $20^{\circ} \mathrm{C}$ to $100^{\circ} \mathrm{C}$. Activation energy for each process was calculated using,

$$
\ln K=\mathrm{A}_{\mathrm{e}} / \mathrm{RT}+\ln \mathrm{B}
$$

where $A_{e}$ is the activation energy $(\mathrm{kJ} / \mathrm{mol}), T$ is temperature in $\mathrm{K}, \mathrm{R}$ is the gas constant $\left(8.31 \mathrm{~J} \mathrm{~K}^{-1} \mathrm{~mol}^{-1}\right)$ and $\mathrm{B}$ is the exponential factor. Activation energy for soluble organic release in the control (conventional heat treatment), MD and SMD was estimated at $0.723,0.415$, and $0.138 \mathrm{~kJ} / \mathrm{mol}$, respectively. Thus, it was identified that the reaction happens in SMD increases and 


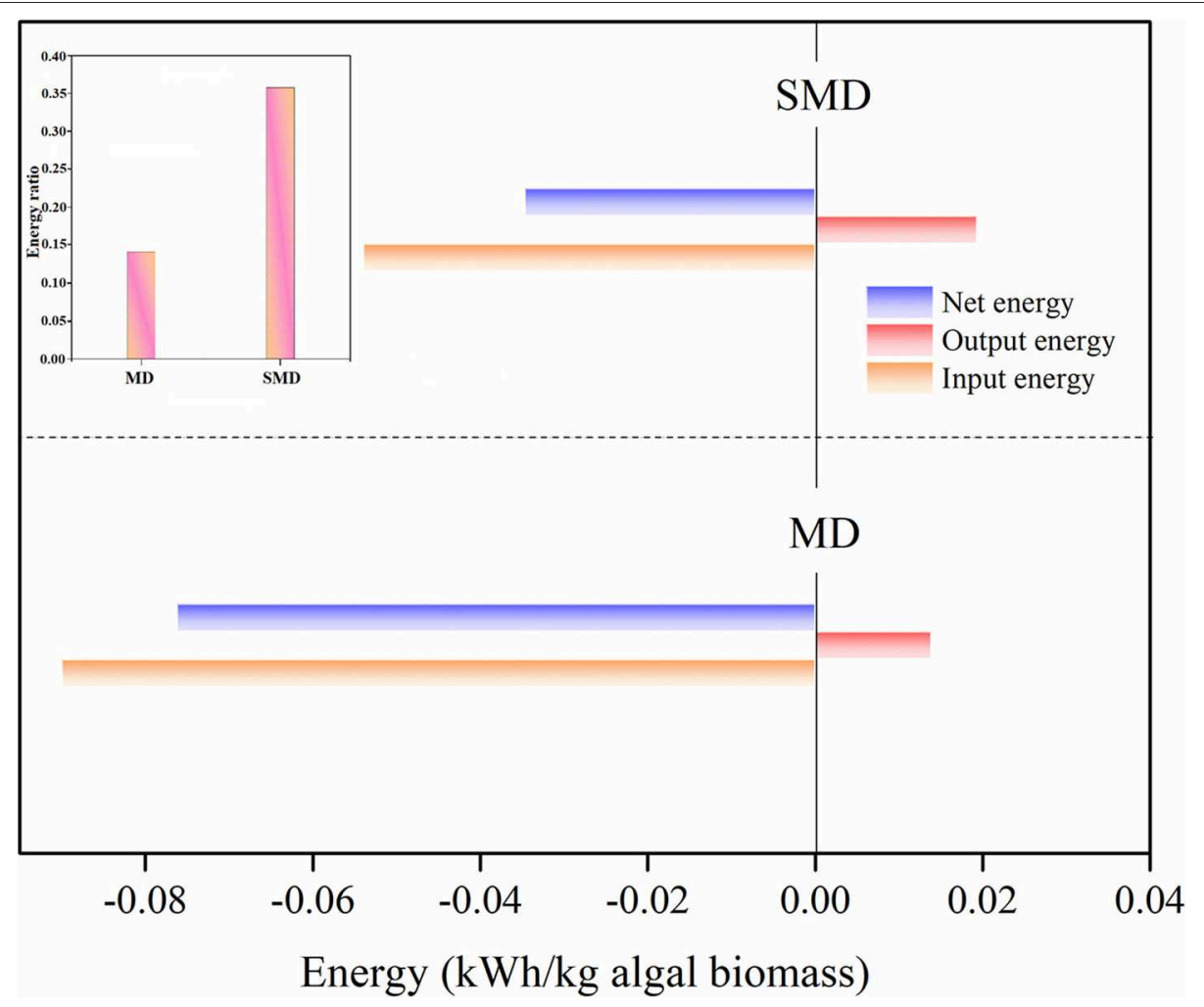

FIGURE 6 | Energy analysis of MD and SMD.

reduces the activation energy when compared to MD and the control treatment. So, surfactant aided microwave disintegration improves the disintegration rate and reduces the energy and time required for it. Table 2 displays the kinetic data relevant to soluble organic release enhanced by microwave irradiation pre-treatment at different temperatures.

\section{Biohydrogen Production Assay}

Biohydrogen production potential for the samples of the control, MD and SMD was assessed using BHP experiments. $\mathrm{H}_{2}$ producing microorganisms struggle to utilize the inner components present in an algal biomass. A proper disintegration method can effectively disintegrate the cell membrane and improve $\mathrm{H}_{2}$ production. SMD exhibited a high $\mathrm{H}_{2}$ production rate compared to the control and MD. This could be because of the rapid hydrolysis of organics, while their consequent consumption of $\mathrm{H}_{2}$ producing microbes were easily available due to combined disintegration. Figure 5 shows the biohydrogen production potential for the control, MD and SMD samples. The hydrogen production rate was noted as 5, 19.4 and $37 \mathrm{~mL}$ $\mathrm{H}_{2} / \mathrm{g} \mathrm{COD}$ at up to 4 days. This low production could be due to the acclimatization process, and the microbes present in the inoculum did not accommodate well in the new environment. Biohydrogen production rapidly increases after the 4th day and maximum production of 19,63 , and $74.5 \mathrm{~mL} \mathrm{H}_{2} / \mathrm{g}$ COD was attained at the 15th day for the control, MD and SMD, respectively. The comparative $\mathrm{H}_{2}$ generation from different algal biomasses is displayed in Table 3. The microorganisms in inoculum took enough time to become acclimatized to the current environment. Owing to optimum disintegration, more biopolymer release occurred, increasing $\mathrm{H}_{2}$ generation. The modified Gompertz model was applied to find $\mathrm{H}_{2}$ generation. The $\mathrm{R}^{2}$ values were observed to be between 0.97 to 0.99 . Table 4 portrays biohydrogen production kinetics in the samples.

\section{Energy Analysis}

An energy analysis of algal samples $(1 \mathrm{~kg})$ was carried out to assess the possibility of SMD on a full scale. The energy spent and gained through hydrogen production was considered for the energy calculation at optimal conditions. Input energy spent in $\mathrm{MD}$ and SMD was calculated to be 0.09 and $0.054 \mathrm{kWh} / \mathrm{kg}$ of algal biomass, respectively. MD required more energy to disintegrate the algal biomass compared to SMD, because of the longer process. SMD therefore saves significantly more energy than MD. On the contrary, the output energy recovered as hydrogen was found to be as high as $0.0193 \mathrm{kWh} / \mathrm{kg}$ algal biomass in SMD compared to $0.0138 \mathrm{kWh} / \mathrm{kg}$ algal biomass in MD. This showed a net energy achievement of $-0.0347 \mathrm{kWh} / \mathrm{kg}$ algal biomass in $\mathrm{SMD}$, while in MD the net energy was $-0.0762 \mathrm{kWh} / \mathrm{kg}$ algal biomass. Based on the energy ratio, SMD obtained a higher value of 0.357 when compared to a low energy ratio achievement of 0.14 in MD. From the above results, it was determined that SMD is a more energy effective process for algal disintegration. Input and output energy calculated for the MD and SMD process are 
tabulated in Table 5. Figure 6 displays the energy analysis of the $\mathrm{MD}$ and SMD process.

\section{CONCLUSION}

This study describes the effective production of biohydrogen through surfactant aided microwave disintegration pretreatment of a marine macroalgal biomass. The maximum hydrogen production of $74.5 \mathrm{~mL} / \mathrm{g}$ COD was achieved with a solubilization of $17.3 \%$ in the SMD process. At a surfactant dosage of 0.0035 $\mathrm{g} / \mathrm{g}$ TS, $1,187 \mathrm{mg} / \mathrm{L}$ of biomolecule content was released. The maximum $\mathrm{H}_{2}$ production of $74.5 \mathrm{~mL} \mathrm{H}_{2} / \mathrm{g} \mathrm{COD}$ and output energy of $0.0193 \mathrm{kWh} / \mathrm{kg}$ algal biomass was recovered as hydrogen in surfactant aided microwave disintegration. It was therefore demonstrated that surfactant aided microwave is a viable method for $\mathrm{H}_{2}$ generation from marine macroalgae.

\section{REFERENCES}

APHA (2005). Standard Methods for the Examination of Water and Wastewater, 21st Edn. Washington, DC: American Public Health Association/American Water Works Association/Water Environment Federation.

Banik, S., Bandyopadhyay, S., and Ganguly, S. (2003). Bioeffects of microwave-a brief review. Bioresour. Technol. 87, 155-159. doi: 10.1016/S0960-8524(02)00169-4

Banu, J. R., Eswari, A. P., Kavitha, S., Kannah, R. Y., Kumar, G., Jamal, M. T., et al. (2018a). Energetically efficient microwave disintegration of waste activated sludge for biofuel production by zeolite : quantification of energy and biodegradability modelling. Int. J. Hydrogen Energy. 44, 1-15. doi: 10.1016/j.ijhydene.2018.06.040

Banu, J. R., Kannah, R. Y., Kavitha, S., Gunasekaran, M., and Kumar, G. (2018b). Novel insights into scalability of biosurfactant combined microwave disintegration of sludge at alkali $\mathrm{pH}$ for achieving profitable bioenergy recovery and net profit. Bioresour. Technol. 267, 281-290. doi: 10.1016/j.biortech.2018.07.046

Banu, J. R., Tamilarasan, T., Kavitha, S., Gunasekaran, M., and Al-Muhtaseb, A. A. H. (2019). Energetically feasible biohydrogen production from sea eelgrass via homogenization through a surfactant, sodium tripolyphosphate. Int. J. Hydrogen Energy 1-11.

Bhuyan, A. K. (2010). On the mechanism of SDS-induced protein denaturation. Biopolymers 93, 186-199. doi: 10.1002/bip.21318

Carvalho, G., Novais, J. M., Pinheiro, H. M., and Vanrolleghem, P. A. (2004). Model development and application for surfactant biodegradation in an acclimatising activated sludge system. Chemosphere 54, 1495-1502. doi: 10.1016/j.chemosphere.2003.08.028

Dhand, C., Dwivedi, N., Loh, X. J., Jie Ying, A. N., Verma, N. K., and Beuerman, R. W. (2015). Methods and strategies for the synthesis of diverse nanoparticles and their applications: a comprehensive overview. RSC Adv. 5, 105003-105037. doi: 10.1039/C5RA19388E

Ebenezer, A. V., Arulazhagan, P., Adish Kumar, S., Yeom, I. T., and Banu, J. R. (2015). Effect of deflocculation on the efficiency of low-energy microwave pretreatment and anaerobic biodegradation of waste activated sludge. Appl. Energy 145, 104-110. doi: 10.1016/j.apenergy.2015.01.133

Eswari, A. P., Kavitha, S., Banu, J. R., Karthikeyan, O. P., and Yeom, I. T. (2017). $\mathrm{H}_{2} \mathrm{O}_{2}$ induced cost effective microwave disintegration of dairy waste activated sludge in acidic environment for efficient biomethane generation. Bioresour. Technol. 244, 688-697. doi: 10.1016/j.biortech.2017.07.078

González-Fernández, C., Sialve, B., Bernet, N., and Steyer, J. P. (2013). Effect of organic loading rate on anaerobic digestion of thermally pretreated Scenedesmus sp. biomass. Bioresour. Technol. 129, 219-223. doi: 10.1016/j.biortech.2012.10.123

Kannah, R. Y., Kavitha, S., Sivashanmugham, P., Kumar, G., Nguyen, D. D., and Chang, S. W. (2019). Biohydrogen production from rice straw: Effect of combinative pretreatment, modelling assessment and

\section{DATA AVAILABILITY}

The datasets generated for this study are available on request to the corresponding author.

\section{AUTHOR CONTRIBUTIONS}

DK carried out the work. AE helped in microwave study. JB supervised the work. SA and J-HP helped and reviewed the work during the research.

\section{SUPPLEMENTARY MATERIAL}

The Supplementary Material for this article can be found online at: https://www.frontiersin.org/articles/10.3389/fenrg. 2019.00078/full\#supplementary-material

energy balance consideration. Int. J. Hydrogen Energy 44, 2203-2215. doi: 10.1016/j.ijhydene.2018.07.201

Kavitha, S., Banu, J. R., Kumar, G., Kaliappan, S., and Yeom, I. T. (2018). Profitable ultrasonic assisted microwave disintegration of sludge biomass: modelling of biomethanation and energy parameter analysis. Bioresour. Technol. 254, 203-213. doi: 10.1016/j.biortech.2018.01.072

Kavitha, S., Stella, P. B. C., Kaliappan, S., Yeom, I. T., and Banu, J. R. (2016). Enhancement of anaerobic degradation of sludge biomass through surfactant-assisted bacterial hydrolysis. Process. Saf. Environ. Prot. 99, 207-215. doi: 10.1016/j.psep.2015.11.009

Kumar, M. D., Kaliappan, S., Gopikumar, S., Zhen, G., and Banu, J. R. (2019). Synergetic pretreatment of algal biomass through $\mathrm{H}_{2} \mathrm{O}_{2}$ induced microwave in acidic condition for biohydrogen production. Fuel 253, 833-839. doi: 10.1016/j.fuel.2019.05.066

Kumar, M. D., Tamilarasan, K., Kaliappan, S., Banu, J. R., Rajkumar, M., and Kim, S. H. (2018). Surfactant assisted disperser pretreatment on the liquefaction of Ulva reticulata and evaluation of biodegradability for energy efficient biofuel production through nonlinear regression modelling. Bioresour. Technol. 255, 116-122. doi: 10.1016/j.biortech.2018.01.116

Liu, H., and Wang, G. (2014). ScienceDirect fermentative hydrogen production from macro- algae Laminaria japonica using anaerobic mixed bacteria. Int. J. Hydrogen Energy 39, 9012-9017. doi: 10.1016/j.ijhydene.2014.03.244

Lowry, O. L., Rossebrough, N. J., Farr, A. L., and Randall, R. J. (1951). Protein measurement with the Folin phenol reagent. J. Biol. Chem. 193, 265-275.

Mohan, S. V., Mohanakrishna, G., Raghavulu, S. V., and Sarma, P. N. (2007). Enhancing biohydrogen production from chemical wastewater treatment in anaerobic sequencing batch biofilm reactor (AnSBBR) by bioaugmenting with selectively enriched kanamycin resistant anaerobic mixed consortia. Int. J. Hydrogen Energy 32, 3284-3292. doi: 10.1016/j.ijhydene.2007.04.043

Mohanakrishna, G., Goud, R. K., Mohan, S. V., and Sarma, P. N. (2010). Enhancing biohydrogen production through sewage supplementation of composite vegetable based market waste. Int. J. Hydrogen Energy 35, 533-541. doi: 10.1016/j.ijhydene.2009.11.002

Mohanty, S., and Mukherji, S. (2012). Alteration in cell surface properties of Burkholderia spp. during surfactant-aided biodegradation of petroleum hydrocarbons. Appl. Microbiol. Biotechnol.94, 193-204. doi: 10.1007/s00253-011-3703-7

Montingelli, M. E., Benyounis, K. Y., Stokes, J., and Olabi, A. G. (2016). Pretreatment of macroalgal biomass for biogas production. Energy Convers. Manag. 108, 202-209. doi: 10.1016/j.enconman.201 5.11 .008

Park, J. H., Yoon, J. J., Park, H. D., Kim, Y. J., Lim, D. J., and Kim, S. H. (2011). Feasibility of biohydrogen production from Gelidium amansii. Int. J. Hydrogen Energy 36, 13997-14003. doi: 10.1016/j.ijhydene.2011.04.003

Pjohn, R., and Anisha, G. S. (2011). Macroalgae and their potential for biofuel. CAB Rev. Perspect. Agric. Vet Sci. Nutr. Nat Resour. 6, 1-15. doi: 10.1079/PAVSNNR20116038 
Rai, P. K., and Singh, S. P. (2016). Integrated dark- and photo-fermentation: recent advances and provisions for improvement. Int. J. Hydrogen Energy 41, 19957-19971. doi: 10.1016/j.ijhydene.2016.08.084

Sambusiti, C., Bellucci, M., Zabaniotou, A., Beneduce, L., and Monlau, F. (2015). Algae as promising feedstocks for fermentative biohydrogen production according to a biorefinery approach: a comprehensive review. Renew. Sustain. Energy Rev. 44, 20-36. doi: 10.1016/j.rser.2014.12.013

Sudhakar, K., and Premalatha, M. (2012). Techno economic analysis of micro algal carbon sequestration and oil production. Int. J. Chem Tech Res. 4, 974-4290.

Tamilarasan, K., Kavitha, S., Banu, J. R., Arulazhagan, P., and Yeom, I. T. (2017). Energy- efficient methane production from macroalgal biomass through chemo disperser liquefaction. Bioresour. Technol. 228, 156-163. doi: 10.1016/j.biortech.2016.12.102

Trevelyan, W. E., Forrest, R. S., and Harrison, J. S. (1952). Determination of yeast carbohydrates with the anthrone reagent. Nature 170, 626-627. doi: $10.1038 / 170626 \mathrm{a} 0$

Wang, J., and Yin, Y. (2018). Fermentative hydrogen production using various biomass-based materials as feedstock. Renew. Sustain. Energy Rev. 92, 284-306. doi: 10.1016/j.rser.2018.04.033

Xia, A., Cheng, J., Ding, L., Lin, R., Song, W., Su, H., et al. (2015). Substrate consumption and hydrogen production via co-fermentation of monomers derived from carbohydrates and proteins in biomass wastes. Appl. Energy 139, 9-16. doi: 10.1016/j.apenergy.2014.11.016

Xia, A., Jacob, A., Rizwan, M., Herrmann, C., and Murphy, J. D. (2016). Production of hydrogen, ethanol and volatile fatty acids through cofermentation of macro- and micro-algae. Bioresour. Technol. 205, 118-125. doi: 10.1016/j.biortech.2016.01.025

Yahmed, N. B., Carrere, H., Marzouki, M. N., and Smaali, I. (2017). Enhancement of biogas production from Ulva sp. by using solid-state fermentation as biological pretreatment. Algal Res. 27, 206-214. doi: 10.1016/j.algal.2017. 09.005

Yang, G., and Wang, J. (2018). Pretreatment of grass waste using combined ionizing radiation-acid treatment for enhancing fermentative hydrogen production. Bioresour. Technol. 255, 7-15. doi: 10.1016/j.biortech.2018. 01.105

Yeneneh, A. M. (2014). Study on performance enhancement of anaerobic digestion of municipal sewage sludge (PhD thesis). Chemical Engineering Department, Curtin University.

Yoo, G., Park, M. S., and Yang, J. W. (2014). Chemical pretreatment of algal biomass. (Elsevier B.V). doi: 10.1016/B978-0-12-800080-9.00012-8

Yu, Y., Chan, W. I., Liao, P. H., and Lo, K. V. (2010). Disinfection and solubilization of sewage sludge using the microwave enhanced advanced oxidation process. J. Hazard. Mater. 181, 1143-1147. doi: 10.1016/j.jhazmat.2010.05.134

Zittel, W., Wurster, R., and Bolkow, L. (1996). Advantages and Disadvantages of Hydrogen. Hydrogen in the Energy Sector. Systemtechnik Gmbitt

Conflict of Interest Statement: The authors declare that the research was conducted in the absence of any commercial or financial relationships that could be construed as a potential conflict of interest.

Copyright (c) 2019 Kumar, Eswari, Park, Adishkumar and Banu. This is an openaccess article distributed under the terms of the Creative Commons Attribution License (CC BY). The use, distribution or reproduction in other forums is permitted, provided the original author(s) and the copyright owner(s) are credited and that the original publication in this journal is cited, in accordance with accepted academic practice. No use, distribution or reproduction is permitted which does not comply with these terms. 